\title{
RECOVERING NON-PECUNIARY LOSSES IN BREACH OF EMPLOYMENT CONTRACT UNDER MALAYSIAN LAW
}

\author{
Ashgar Ali Ali Mohamed ${ }^{1 *}$, Mohd Akram Shair Mohamed ${ }^{2}$ \\ Farheen Baig Sardar Baig ${ }^{3}$ \\ ${ }^{1}$ Prof. Dr., International Islamic University Malaysia, Kuala Lumpur, Malaysia \\ ashgar@iium.edu.my \\ ${ }^{2}$ Prof. Dr., International Islamic University Malaysia, Kuala Lumpur, Malaysia \\ akram@iium.edu.my \\ ${ }^{3}$ Assoc. Prof. Dr., International Islamic University Malaysia, Kuala Lumpur, Malaysia \\ baigfarheen007@yahoo.com \\ ${ }^{*}$ Corresponding author
}

\begin{abstract}
Dismissal from employment is the prerogative of the employer. An impending dismissal must be carried out fairly with the affected employee given the right to be heard. When a dismissal has been effected in highhanded manner, it may have real prospect of humiliation and embarrassment to the employee. Besides besmirching his reputation, it can also affect the employee's ability to seek new employment, forcing him to accept employment offering lower wages than what would have been expected in the type of work, or even causing him ill health, among others. The availability of compensation for non-pecuniary losses such as wounded feelings or the effect of the dismissal on his reputation or the chances of finding other employment arising from the manner of the dismissal were excluded by the House of Lords in their landmark case of Addis $v$ Gramophone Co Ltd [1909] AC 488. Such compensation was disallowed mainly because the common law perceived employment contract as an ordinary commercial contract and that such contract is not intended to shelter the parties from anxiety. The situation in the $21^{\text {st }}$ century is however markedly different from 1909 where with the advancement of information technology, the transmission of information regarding the manner of a dismissal is borderless and thus, having far reaching consequences on the claimant. In light of the above, this paper discusses the high-handed manner of a dismissal, its impact on the employee and the availability of compensation for non-pecuniary losses under the statutory unfair or unjustifiable dismissal. Reference is made to the law and practice in selected countries namely, the United Kingdom, Canada, Australia and New Zealand. In the context of Malaysia, it will be contended that an employee that had been subjected to deplorable acts of victimisation while in employment and any highhanded manner of a dismissal, among others, should be awarded the non-pecuniary compensation.
\end{abstract}

Keywords: Employment Law, Non-pecuniary losses, Recovering compensation 


\section{INTRODUCTION}

Dismissal from employment is, in most circumstances, a distressing experience that has both financial repercussion and psychological effects. High-handed manner of a dismissal is likely to affect the reputation and standing of a person, where the higher the status and responsibility, the greater the effect of his dismissal. The dismissed worker may suffer non-pecuniary harm such as serious trauma from being dismissed, the discredit of being an unemployed person with real prospects of humiliation and embarrassment. He may also suffer from deteriorating psychological health with stress related illness such as hypertension, cardiac disorders, and gastric ulcers, among others (Carrie R Leana and Daniel C Feldman (1992). In Sunmugam Subramaniam v JG Containers (M) Sdn Bhd \& Anor [2000] 6 CLJ 521, the High Court noted inter alia, that the dismissed employee would have to suffer economic misery and mental torture while being unemployed and awaiting decision of the court. Even the misery of being obliged to remain idle without work would constitute an unbearable burden.

Likewise, victimising an employee while in employment such as harassing or humiliating the employee, particularly in the presence of other junior staff, changing employee's job content or terms without consultation, falsely accusing the employee of misconduct such as theft or of being incapable of carrying out the job, a fundamental demotion with reduced responsibilities and/or where his newly assigned position involves a substantial reduction in salary, bonus, benefits, status, responsibilities, authority or any combination of these factors, and even forced resignation, among others, are examples of conducts which are likely to affect the employee mentally. For example, in Bina Goodyear Bhd v Subramaniam Kanaiappan [2004] 3 ILR 148, the claimant was subjected to humiliation, embarrassment and mental distress which subsequently made him to tender his resignation. In Subramaniam's case, the claimant alleged that his supervisor had used intemperate language on him in the presence of other employees on several occasions and this had affected him mentally. The claimant considered himself as been dismissed and thereafter brought a claim against the employer for constructive dismissal. Having said the above, the issue discussed in this paper is whether an employee whose dismissal was affected in high-handed manner is entitled to recover damages for non-pecuniary losses. Reference is made to law and practice in selected countries namely, United Kingdom, Canada, Australia, New Zealand and Malaysia. This comparative analysis will provide valuable guidance to the current thinking on this subject and based on the findings, the researchers would be able to propose necessary reform in Malaysia.

\section{HIGH-HANDED MANNER OF DISMISSAL}

Unlike in genuine redundancy situations necessitated by genuine commercial and economic considerations, where both employer and worker would have to face the bitter reality, in dismissal cases, however, the employer has without just cause or excuse violated the worker's job security. The aggrieved workman would not only have suffered economic losses but also the non-pecuniary losses in various forms, such as serious trauma of being dismissed and the discredit of being an unemployed person, among others. To make things worse, if the dismissal has been affected in a high-handed manner, it may have a real prospect of humiliation and embarrassment. There will be suspicion and misconception among the family members and friends of the reasons for his termination. . He will be hurt and embarrassed by people talking about his abrupt manner of the dismissal. Furthermore, the effect of the abrupt manner of his dismissal on his reputation may hamper his chances of finding other employment.

For example, in Mohd Ridzwan Abdul Razak v Asmah Hj Mohd Nor [2015] 4 CLJ 295 , the appellant, General Manager of the Pilgrims Fund Board, was alleged to have sexually harassed the respondent, a staff member who was under his supervision. The appellant was alleged to have uttered vulgar remarks, dirty jokes that were sexually oriented and had repeatedly offered to take the respondent as his second wife. However, a disciplinary action could not be taken against the appellant as there was insufficient evidence. Nevertheless, the company issued a strong administrative reprimand to the appellant and transferred the respondent to the Legal Division in the company. In the meantime, the appellant lodged a complaint with the company seeking disciplinary action be taken against the respondent for defaming him without any proof. However, the request was declined by the company. Hence, this defamation action by the appellant against the respondent seeking inter alia, damages. Meanwhile, the respondent counterclaimed damages for mental distress arising from the appellant's alleged misconducts.

As the appellant had failed to prove the claim his application was dismissed by the High Court. The respondent's counterclaim however was allowed as the respondent had followed the proper procedure in lodging the complaint with the company and that there was ample evidence to show that the appellant had uttered vulgar and/or sexually explicit statements directed at the respondent or within the presence of the respondent. Dissatisfied, the appellant appealed to the Court of Appeal on the ground that the trial judge had 
erred in dismissing his claim for defamation and allowing the respondent's counterclaim. In dismissing the appeal with costs, Zaharah Ibrahim JCA, delivering the judgment of the court, stated inter alia, that 'the acts of sexual harassment were serious enough so as to cause adverse psychological effect on the victim, those acts would fall within the tort of intentionally causing nervous shock similar to that in Wilkinson $v$ Downton. The time was now appropriate for the tort of intentionally causing/inflicting nervous shock to be recognized in this country, as had been done in Canada.'

Her Ladyship further stated: "The evidence led before the High Court indicated that the defendant was an emotionally vulnerable person, in the sense that she appeared to be under some emotional pressure and had migraine and pains in her leg. She clearly would be more susceptible to being adversely affected by the kind of objectionable remarks made by the plaintiff, and the fact that the plaintiff continually made such remarks indicated that he knew that such remarks would make the defendant extremely uncomfortable. After her complaint was investigated, the defendant was placed in another department, assigned to do duties which had nothing to do with the job she was hired to do. This transfer had a direct nexus to the acts of the plaintiff that she lodged a complaint about. A psychiatrist had diagnosed her as having major depression which was caused by being harassed by the plaintiff that continued to haunt her even after she left LTH. The defendant was under so much emotional stress that she could no longer bear being in LTH and left to take up a post in Sabah. The acts of the plaintiff uttering the remarks which amounted to sexual harassment and with the knowledge of her vulnerability fell within the ambit of the tort of intentionally causing nervous shock."

It may be further added that dignity and reputation of an employee may also be besmirched by the employer's conduct for example, calling the employee a 'bitch' (Isle of Wight Tourist Board v JJ Coombes [1976] IRLR 413), accusing the employee of theft without adequate supporting evidence (Robinson $v$ Crompton Parkinson Ltd [1978] ICR 401) or unjustifiably undermining the supervisor's authority in the presence of other employees (Associated Tyre Specialist (Eastern) Ltd [1977] ICR 218; Waterhouse (Bond St) Ltd v Lynn [1978] ICR 205). Similarly, dismissing an employee without clear warning (Country Fare (Christchurch) Ltd v Dixey [1995] 2 ERNZ 372) or assessing an employee's performance as poor on grounds of malice (Courtaulds Northern Textiles $v$ Andrew [1979] IRLR 84).

It can also arise when an employee is demoted or his wages were reduced without justification (Moser $v$ Farm Credit Corp [1993] 2 WWR 122), or there is a failure to give reasonable support to perform duties without disruption and harassment (Wigan Borough Council v Davies [1979] IRLR 127), failure to comply with and to disregard the agreed procedures designed for a fair resolution of grievances accompanied by consequential arbitrariness and capriciousness in the decision to transfer an employee (Mayban Assurance Bhd v Chern Geok Eng [2001] 2 ILR 372) and the drastic change of conditions of employment (Pelabuhan Tanjung Pelepas Sdn Bhd v Thangasamy Brown Dn Gnanayutham [2003] 1 ILR 62), to mention but a few.

In Bina Goodyear Bhd v Subramaniam Kanaiappan [2004] 3 ILR 148, the company's site supervisor, COW1, had used intemperate language on the claimant in the presence of other employees during a discussion. The incident had caused humiliation, embarrassment and mental distress that made him tender his resignation. Again, in Abbott Laboratories (Malaysia) Sdn Bhd v Yeoh Siew Tin [2005] 1 ILR 43, the claimant, a senior medical representative of the company alleged that she had been a victim of abusive words by the superior and that she suffered mental distress as a result of the company's environment. Likewise, in Darmawatti Dahari v Malaysia Mining Corporation Bhd [2005] 1 ILR 93, the claimant, a group company secretary, tendered her resignation because of the victimisation and oppression by COW1, head of the human resource at the material time. She alleged that she had suffered humiliation in - being excluded from meetings whilst she was the group company secretary for ten years. Finally, in Amngran Govindasamy $v$ Lifeline Innovators Sdn Bhd [2010] 2 LNS 0847, the claimant was initially forced to signed the resignation letter which he refused. He was then removed from the office by force and was not allowed to report to work and when he went to the office the next day. He was not allowed entry as the automatic door no longer responds to his door key number. The claimant stated that as a consequence of the above ordeal, he suffered mental distress and depression.

The abovementioned conduct of the employer is contrary to the implied duty of trust and confidence between the employer and employee (Isle of Wight Tourist Board v JJ Coombes [1976] 1 ILR 413). The implied duty of trust and confidence provides inter alia, that employer should not conduct itself in a manner calculated or likely to destroy or seriously damage the relationship of confidence and trust between the parties. Further, the employer has a duty to treat the workers fairly and reasonably during employment and where dismissal is inevitable, it should be carried out in a justifiable manner (Vorvis $v$ Insurance Corporation of British Columbia (1989) 58 DLR (4th) 193). It is also implied by the terms of trust and confidence that the employee would be treated in such a manner as to enable him or her to retain his or her dignity and status.

In Wallace v United Grain Growers Ltd (1998) 152 DLR (4th) 1, a Canadian case, lacobucci J., delivering the 
judgment for the majority, stated: 'The law should be mindful of the acute vulnerability of terminated employee's and ensure their protection by encouraging proper conduct and preventing all injurious losses which might flow from acts of bad faith or unfair dealing on dismissal, both tangible and intangible. I note that there may be those who would say that this approach imposes an onerous obligation on employers. I would respond simply by saying that I fail to see how it can be onerous to treat people fairly, responsibly and decently at a time of trauma and despair. In my view, the reasonable person would expect such treatment. So should the law.' Again, in Malik v Bank of Credit and Commerce International S.A. (in Liquidation) and Mahmud v Bank of Credit and Commerce International S.A. in Liquidation) [1997] 3 All ER 1, Lord Nicholls of Birkenhead, whose opinion was conquered by Lord Goff of Chieveley and Lord Mackay of Clashfern, stated:

'Employers may be under no common law obligation, through the medium of an implied contractual term of general application, to take steps to improve their employees' future job prospects. But failure to improve is one thing, positively to damage is another. Employment, and job prospects, is a matter of vital concern to most people. Jobs of all descriptions are less secure than formerly, people change jobs more frequently, and the job market is not always buoyant. Everyone knows this. An employment contract creates a close personal relationship, where there is often a disparity of power between the parties. Frequently the employee is vulnerable. Although the underlying purpose of the trust and confidence term is to protect the employment relationship, there can be nothing unfairly onerous or unreasonable in requiring an employer who breaches the trust and confidence term to be liable if he thereby causes continuing financial loss of a nature that was reasonably foreseeable. Employers must take care not to damage their employees' future employment prospects, by harsh and oppressive behaviour or by any other form of conduct which is unacceptable today as falling below the standards set by the implied trust and confidence term.'

What is apparent from the above is that the employment contract creates a close personal relationship employer and thus, as Lord Nicholls of Birkenhead, in Malik's case, aptly noted 'employers must take care not to damage their employees' future employment prospects, by harsh and oppressive behaviour or by any other form of conduct which is unacceptable today as falling below the standards set by the implied trust and confidence term'. Hence, in their dealing with the employee, the employer is expected to conduct itself properly and should prevent all injurious losses which might flow from acts of bad faith or unfair dealing on dismissal, both tangible and intangible.

\section{NON-PECUNIARY LOSSES FOR BREACH OF EMPLOYMENT CONTRACT}

Humiliation and mental distress arising from the egregious way or circumstances in which the act was committed is actionable in the sphere of Tort law. For example, in Mas Anum Samiran v Othman Mohamed, the plaintiff, a former personal assistant of the defendant, alleged that she was sexually harassed by her former boss, the defendant. The allegation included physical and verbal harassment by the defendant throughout the time she served as his personal assistant. Because of the repeated incidents of sexual harassment, the plaintiff suffered anxiety, stress and humiliation, and was forced to resign from her job. As the plaintiff had succeeded in proving the elements of sexual harassment by defendant, the Sessions Court awarded the plaintiff a sum of RM25,000 which included both tangible and intangible losses.

Again, in $L v$ Burton DCEO15/2009, a Hong Kong case, the defendant sexually harassed the plaintiff during the plaintiff's short-lived employment in the company. The employment relationship between the plaintiff and the defendant deteriorated when she refused the sexual advances by the defendant. The plaintiff's dismissal from the company was extremely high-handed and openly oppressive of the plaintiff's personal dignity. The plaintiff was extremely distressed and humiliated. As a result of the sexual harassment she suffered anxiety, stress, humiliation, physical injury and insomnia. The court found in favour of the plaintiff and awarded her a sum of $\$ 100,000$ as damages which included the non-pecuniary losses flowing from both the acts of sexual harassment and dismissal.

In yet another Hong Kong case of Yuen Sha Sha $v$ Tse Chi Pan [1999] 1 HKC 731, the defendant had without the knowledge or consent of the plaintiff, secretly recorded images of the plaintiff undressing and changing her clothes. In a civil action against the defendant, the plaintiff alleged that she suffered loss and damages by reason of the sexual harassment and prayed inter alia, for compensation for injury to feelings pursuant to ss 76(6) and 76(3A)(e) of the Sex Discrimination Ordinance. In allowing the application, it was held that the defendant's video-taping of the plaintiff dressing and undressing without her consent constituted an act of sexual harassment which was rendered unlawful under s 39(3) of Pt IV of the Ordinance. Accordingly, a sum of $\$ 50,000$ was awarded as damages for injury to feelings.

However, in the context of employment law, the courts are generally reluctant, except quite recently, to include injury to feelings and mental distress as factors relevant when considering reasonable compensation in favour of the unfairly dismissed worker. The exclusion of the non-pecuniary losses for wounded feelings 
arising from the manner of the dismissal or the effect of the dismissal on his reputation or the chances of finding other employment among others is embedded in the common law principle since 1909 in the House of Lords decision in Addis v Gramophone Co Ltd [1909] AC 488.

It Addis case, the majority Law Lords comprised of Lord Loreburn LC, Lord Atkinson, Lord Corell, Lord Shaw of Dunfermline and Lord James of Hereford held inter alia, that in wrongful dismissal, damages cannot be increased by reason of the manner of the dismissal whether in respect of his wounded feelings or the prejudicial effect upon his reputation and chances of finding other employment. The exclusion of such losses was primarily because the common law perceived contract of employment as an ordinary commercial contract and that such contract is not intended to shelter the parties from anxiety. In breach of contract cases, the general rule is that damages are awarded to restore the wronged party to the position he/she would have been in had the contract not been broken. In Addis's case, Lord Atkinson, delivering the judgment for the majority, stated inter alia, that as long as the plaintiff frames his cause of action in contract, he is limited to contract remedies, which flow from the breach of an ordinary commercial contract.

Recently, however, the House of Lords in Malik $v$ Bank of Credit and Commerce International S.A. (in Liquidation) and Mahmud $v$ Bank of Credit and Commerce International S.A. in Liquidation) [1997] 3 All ER 1, whilst affirming the decision in Addis's case, allowed the recovery of compensation for non-pecuniary losses in exceptional circumstances. The law lords unanimously recognized that there is a reasonable cause of action in breach of the implied obligation of trust and confidence - a term not known when Addis was decided. Lord Nicholls of Birkenhead stated: "Addis v Gramophone Co. Ltd. was decided in the days before this implied term was adumbrated." His Lordship further stated: "employers must take care not to damage their employees' future employment prospects, by harsh and oppressive behavior or by any other form of conduct which is unacceptable today as falling below the standards set by the implied trust and confidence term." In Commonwealth Bank of Australia v Barker [2014] 312 ALR 356, the High Court of Australia stated inter alia, that "the term of trust and confidence recognized in Malik...imposes obligations on an employer not to engage in "trust-destroying conduct" which may sound in damages if breached." In Woods v WM Car Services (Peterborough) Ltd [1981] IRLR 347, the English Employment Appeal Tribunal held inter alia, that destruction or serious damage to the relationship of confidence and trust between an employer and employee is a fundamental breach amounting to a repudiation of the contract of employment.

In the light of the House of Lords decision in Malik's case, the recoverable of non-pecuniary losses is possible in the following circumstances: if the manner of the dismissal besmirched a worker's reputation thereby making it difficult for him to seek new employment; or forcing him to accept employment offering lower wages than what would have been expected in the type of work; or if the manner of the dismissal causes him ill health thereby making him unfit to secure re-employment, among others (Ashgar Ali (2002)). In short, an employer who breaches the implied term of trust and confidence will be liable if he thereby causes the employee continuous financial loss of a nature that was reasonably foreseeable.

\section{RECOVERY OF NON-PECUNIARY LOSSES IN MALAYSIA}

In the context of Malaysia, the former Federal Court in Fung Keong Rubber Manufacturing (M) Sdn Bhd $v$ Lee Eng Kiat [1981] 1 MLJ 238, and the Court of Appeal in Penang Port Commission v Kanawangi s/o Seperumaniam [1996] 3 MLJ 427, had followed the Addis doctrine. Despite the above, the High Court in Kanawangi s/o Seperumaniam v Penang Port Commission [2001] 5 MLJ 433, made the strongest criticism of Addis doctrine. Faiza Thamby Chik J, delivering the judgment of the court, described the Addis doctrine as "archaic and unfair". It was stated that the Addis doctrine does not represent good law. It is submitted that based on the doctrine of stare decisis, no matter how unfair the Addis doctrine might be, the approach taken by the superior courts in Malaysia binds the courts below. In this regard, since the Addis doctrine had been cited with approval by the former Federal Court in Fung Keong Rubber Manufacturing (M) Sdn Bhd and by the Court of Appeal in Penang Port Commission, the decision binds the High Court. As Gopal Sri Ram JCA rightly noted in Tai Chai Yu v The Chief Registrar of the Federal Court [1998] 2 CLJ 358: "A final decision of the Federal Court, once pronounced, is binding upon the parties thereto and its correctness may only be questioned in a subsequent case where the identical point of law arises for decision".

It may be further added that the reception or application of the Addis doctrine in Malaysia is governed by sections 3 of the Civil Law Act 1956 (Revised 1972) which empowered the courts to apply English common law, rules of equity, and statutes in civil cases where no specific laws have been enacted. In relation to the application of English law pursuant to the abovementioned section, it is also worthwhile reproducing the observation by Abdul Hamid Mohamad FCJ (as he then was), in Majlis Perbandaran Ampang Jaya $v$ Steven Phao Cheng Loon \& 81 Others [2006] 2 MU 389. In delivering the judgment of the Federal Court, His Lordship stated: 'It is not the function of the court to enter into arguments regarding the desirability or 
otherwise of the provision. That is a matter for Parliament to decide. As far as the court is concerned, until now, that is the law and the court is duty bound to apply it. In so doing, the provision is clear that even the application of common law of England as administered in England on 7 April 1956 is subject to the conditions that no provision has been made by statute law and that it is 'permissible' considering the 'circumstances of the States of Malaysia' and their 'respective inhabitants'. That is not to say that post - 7 April 1956 developments are totally irrelevant and must be ignored altogether. If the court finds that the common law of England as at 7 April 1956, is not 'permissible', it is open to the court to consider post - 7 April 1956 developments or even the law in other jurisdictions or sources.'

It may be further added that in Lembaga Tatatertib Perkhidmatan Awam Hospital Besar Pualu Pinang and Anor v Utra Badi K Perumal [2000] 3 CLJ 224, the Court of Appeal stated inter alia, that 'right to life' in Article $5(1)$ of the Federal Constitution should necessarily include 'right to reputation'. Gopal Sri Ram JCA, delivering the judgment of the Court, stated: 'The authorities are now well settled that the punishment of dismissal deprives a person of his livelihood and therefore of his "life" within the meaning of that expression in Art 5(1) of the Federal Constitution ... Similarly, when a person is deprived of his reputation, it would in my judgment, amount to a deprivation of "life" within Art 5(1) of the Federal Constitution. The right to reputation is part and parcel of human dignity. And it is the fundamental right of every person within the shores of Malaysia to live with common human dignity.'

Be that as it may, it is noteworthy that the common law principles in Addis's case have no application in the sphere of industrial jurisprudence. This is primarily because, unlike at common law, adjudication of labour disputes under the industrial jurisprudence are based on equity and good conscience. Although that being the case, however a review of the Industrial Relations Act 1967 does not provide details on the assessment of monetary award for successful unfair dismissal claims except to mention in section 30(6A) of the Act that the Court in making the award shall take into consideration the factors specified in the second schedule. The factors specified in second schedule are as follows:

(1) In the event that back wages are to be given, such back wages shall not exceed twenty-four months' back wages from the date of dismissal based on the last-drawn salary of the person who has been dismissed without just cause or excuse;

(2) In the case of a probationer who has been dismissed without just cause or excuse, any back wages given shall not exceed twelve months' back wages from the date of dismissal based on his lastdrawn salary;

(3) Where there is post-dismissal earnings, a percentage of such earnings, to be decided by the Court, shall be deducted from the back wages given;

(4) Any relief given shall not include any compensation for loss of future earnings; and

(5) Any relief given shall take into account contributory misconduct of the workman.

Despite the above guidelines, the Industrial Court is still guided by the Practice Note No. 1 of 1987 which was introduced with a view of ensuring uniformity and consistency in the assessment of monetary award of the Industrial Court. In R. Rama Chandran v The Industrial Court of Malaysia and Anor [1997] 1 MLJ 145, Edgar Joseph Jr. FCJ stated inter alia, that the above practice directive has made it easier for the assessment of the monetary award. The said practice directive provides for the payment of the arrears of wages, known as back wages or back pay and compensation in lieu of reinstatement. The current practice of the Industrial Court however is that the Court is usually awards a fixed rate of one month's wages for each completed year of service. Only in exceptional circumstances may the Court award exemplary compensation in excess of its normal rate as per the practice directive of the Court. For example, in Pelabuhan Tanjung Pelepas Sdn Bhd v Thangasamy Brown Dn Gnanayutham [2003] 1 ILR 62, the Industrial Court awarded the claimant among others, non-pecuniary losses arising from the manner of the dismissal. In the above case, the claimant who had been subject to deplorable acts of victimisation while in employment, and who had contributed much to the company during the short stint of his tenure before being constructively dismissed, was awarded exemplary compensation, an equivalent of three months remuneration.

Again, in Chin Sooi Chon v Tamco Corporate Holdings Sdn Bhd [2007] 2 LNS 2279, the claimant was able to establish to the satisfaction of the court that he was driven out of his employment by the acts and omissions of the company. In relation to such conduct, the Court awarded the claimant, in addition to the normal monetary award, a sum of RM 8,000 to reflect the Court's findings that the company's termination of the claimant was capricious. Similarly, in Palaraman Panadian v Suria Spices Sdn Bhd [2011] 2 LNS 1124, the claimant, a storekeeper, was chastised by the company manager without any reasons. He had asked the claimant to leave the company and that his termination from the employ of the company was effected 
immediately. The Industrial Court held that the company had dismissed the claimant without just cause or excuse. Although the claimant's tenure with the company was short, however because of the highhanded and unreasonable manner in which he was dismissed by the company, the Court ordered the company to pay the claimant 12 months of back wages.

However, in vast majority of the Industrial Court awards, the Court tend to follow strictly the assessment of monetary award as contained in the practice directive of 1987 without including the compensation for nonpecuniary losses. It is submitted that in the assessment of monetary compensation, many factors ought to be taken into consideration, which includes inter alia, the loss of security of tenure, loss of seniority gained from the years of his service, the fact that the workman would have to secure a new career part all over again in his new employment, the fact that he may have to start from low rung with the possible reduced wages, circumstances of dismissal, nature of charge levelled against the workman, and the effect of the dismissal on his reputation, among others. In some case, the above was reflected in the award of the Industrial Court. For example, in DNT (Malaysia) Sdn Bhd v Kek Boon Hua [1998] 3 ILR 16, the Industrial Court noted inter alia, that in determining whether the monetary award was justified, factors such as claimant's age, mental distress and suffering and his unblemished record with the company ought to be taken into consideration. Again, in $R$ Rama Chandran $v$ The Industrial Courts of Malaysia, the Federal Court while holding that reinstatement is not the appropriate remedy in this case, stated: 'the Employee was now 51 years old, had been out of employment for seven years and had lost touch with his work. It was doubtful if he could fit in the society where he used to work and where he was not wanted. Under the circumstances, sending him back to the Employer would cause him more mental distress and suffering'.

\section{APPROACH IN OTHER JURISDICTIONS}

\subsection{United Kingdom}

It would be worthwhile referring to the practice in some developed countries where it is observed that discretion has been conferred on the relevant authorities to assess compensation to include the above losses. For example, the English Employment Rights Act 1996, section 123 provides that the amount of compensation shall...be such amount as the court or tribunal considers just and equitable in all the circumstances having regard to the loss sustained by the aggrieved party in consequence of the matter to which the complaint relates, in so far as that loss was attributable to action taken on behalf of the party in default. In Johnson v Unisys Ltd [2001] ICR 480, the appellant had been summarily dismissed and had received compensation for unfair dismissal from the employment tribunal. He also brought a common law claim for damages arising from the manner of dismissal, which, he alleged, had caused him to suffer a mental breakdown. Lord Hoffmann, delivering the judgment of the House, stated inter alia, that the statute empowered the employment tribunal to award compensation for damage to reputation and distress.

In Johnson's case, the House of Lords had given a broader interpretation to the word 'loss' in section 123, which in their lordship's opinion is not merely confined to financial losses but includes the non-pecuniary losses arising from the manner of the dismissal such as damage to reputation in the community or to family life. In other words, the manner of a dismissal is a relevant factor in the computation of reasonable compensation if there is cogent evidence that the manner of the dismissal has caused financial loss, such as by making it more difficult to find future employment (see Vaughan $v$ Weighpack Ltd [1974] IRLR 105).

\subsection{Australia}

Section 170EE (2) of the Workplace Relations Act 1996 (Cth) provides: "If the Court thinks, in respect of a contravention of a provision of this Division....constituted by the termination of employment of an employee, that the reinstatement of the employee is impracticable, the Court may, if the Court considers it appropriate in all the circumstances of the case, make an order requiring the employer to pay to the employee compensation of such amount as the Court thinks appropriate". The above section had been discussed by the Industrial Relations Court of Australia (Full Court) in Burazin v Blacktown City Guardian Pty Ltd [1997] 142 ALR 144, where the Full Court adopted a liberal interpretation of the word 'compensation' in the said section. It was stated that the term 'compensation' in the above section is not restricted to pecuniary losses alone but may include in the assessment, the non-pecuniary loss flowing from the harsh, unjust and unreasonable termination of the employment contract. In Burazin's case, the claimant, a part-time sales representative, had complained to her superior regarding the non-payment of commission to her. As a result of the complaint, she suffered a series of ugly incidents perpetrated by her superior before being forcibly removed from the premises by two police officers and dismissed without valid grounds. Again, in Emmerson $v$ Housing Industry Association Ltd [1999] FCA 500, the court awarded damages for pain, shock and humiliation and for damage to the applicant's inability to obtain alternative employment due to the arbitrary manner of the dismissal. 


\subsection{New Zealand}

In New Zealand, the Employment Relations Act 2000, section 123 expressly provides that: "Where the Authority or the Court determines that an employee has a personal grievance, it may, in settling the grievance, provide for any one or more of the following remedies:

(a) Reinstatement of the employee in the employee's former position or the placement of the employee in a position no less advantageous to the employee;

(b) The reimbursement to the employee of a sum equal to the whole or any part of the wages or other money lost by the employee as a result of the grievance;

(c) The payment to the employee of compensation by the employee's employer, including compensation for - (i) Humiliation, loss of dignity, and injury to the feelings of the employee; and (ii) Loss of any benefit, whether or not of a monetary kind, which the employee might reasonably have been expected to obtain if the personal grievance had not arisen.

What is apparent from the above provision is that the compensation payable to an unjustifiably dismissed employee includes compensation for humiliation, loss of dignity, and injury to the feelings of the employee. In other words, compensation for non-pecuniary losses is expressly allowed by the New Zealand Employment Relations Act 2000, section 123.

\subsection{Canada}

Finally in Canada, in Hickey's Building Supplies Limited v Sheppard 2014 NLCA 43, the Newfoundland Court of Appeal noted that the Courts in Canada are becoming more willing to award damages for mental distress for breach of a contract. In Sheppard's case, the contractor was ordered to compensate the homeowners for the mental distress resulting from the uneven floors. Again, in Fidler $v$ Sun Life Assurance Co of Canada [2006] 2 SCR 3, the plaintiff, a bank receptionist, had, since January 1991, received the long-term disability benefits under her employee group insurance plan. However, in December 1998, despite medical evidence of incapacity, the insurer terminated the long-term disability benefits. The trial judge awarded the plaintiff a sum of $\$ 20,000$ as damages for mental distress. On appeal to the Court of Appeal and subsequently to the Supreme Court of Canada, the above award was affirmed. It was stated that damages for mental distress is recoverable when such damages were in the reasonable contemplation of the parties at the time the contract was made.

In the context of employment law, the Canadian Labour Code, RSC, 1985, section 242(4), states that an adjudicator in computing appropriate compensation for unjust dismissal may include firstly, the harsh and unfair manner in which the dismissal took place, secondly, the effect of the dismissal on the employee's career development and thirdly, the prospect for alternative employment. In Joseph Wilson $v$ Atomic Energy of Canada Limited (2016) SCC 29, Supreme Court of Canada was faced with the issue whether a dismissal without cause together with a sizeable severance package meant that the dismissal was a just one. The Court noted that the entire purpose of the statutory scheme was to ensure that non-unionized federal employees would be entitled to protection from being dismissed without cause under Part III of the Code. In relation to the award of mental distress or punitive damages, the Court in Joseph Wilson's case noted inter alia, that the adjudicators routinely award such damages 'where the employer's conduct in dismissing an employee is egregious or in bad faith'. For example, in Poulter v Gull Bay First Nation (2011) CarswellNat 3466, a sum of $\$ 10,000$ was awarded for bullying, demeaning, and harassing conduct that led to a constructive dismissal. Again, in Morrisseau v Tootinaowaziibeeng First Nation (2004) 39 C.C.E.L. (3d) 134, the employee was awarded three extra months of salary and benefits payable due to the employer's callous behaviour in dismissing the employee. Lastly, in Parrish \& Heinbecker Ltd v Knight (2006) CarswellNat 6950, four months' salary was ordered as punitive damages for the employer's conduct in dismissing the employee without cause or notice. Reverting back to Joseph Wilson's case, the Supreme Court of Court stated: "These remedies are available in the civil courts and they are routinely awarded as remedies for wrongful dismissals. They are equally available to employees who challenge the lawfulness of their dismissal through the adjudicative provisions of the Code."

\section{CONCLUSION}

The general rule in breach of contract cases are that damages are awarded to restore the wronged party to the position he/she would have been in had the contract not been broken. In the sphere of employment law for wrongful dismissal, damages cannot be increased by reason of the manner of the dismissal whether in respect of his wounded feelings or the prejudicial effect upon his reputation and chances of finding other employment. The House of Lords in Malik's case, whilst affirming the decision in Addis's case, allowed the 
recovery of non-pecuniary losses for wounded feelings in exceptional circumstances. The reception or application of the Addis doctrine in Malaysia is governed by sections 3 of the Civil Law Act 1956 (Revised 1972). The former Federal Court in Fung Keong Rubber Manufacturing's case, and the Court of Appeal in Penang Port Commission's case, had followed the Addis doctrine. Hence, in Malaysia, following the Addis doctrine, an employee whose dismissal was affected in high-handed manner is not entitled to recover damages for non-pecuniary losses. Be that as it may, Addis doctrine is a common law principle which is not applicable in the sphere of statutory settings. As noted in the paper, the courts in the United Kingdom, Canada, Australia and New Zealand have allowed the recovery of non-pecuniary losses under their statutory provisions. In New Zealand for example, an unjustifiably dismissed employee is entitled to recover compensation for humiliation, loss of dignity, and injury to the feelings.

Having considered the law in the abovementioned jurisdictions, and bearing in mind the purpose of monetary compensation for dismissal without just cause or excuse, it is submitted that in Malaysia, the legislature should expressly confer power on the Industrial Court to award compensation for non-pecuniary losses when the manner of the dismissal had affected the employee's reputation and dignity. In the alternative, it is argued that section 30(6) of the Industrial Relations Act 1967 has conferred on the Industrial Court a certain degree of flexibility in that in making an award, the court may include any matter or thing which it thinks necessary or expedient for the purpose of settling the reference under the IRA s 20(3). The key words to be noted from section 30(6) is that the 'Court shall not be restricted' and 'may include in the award any matter or thing which it thinks necessary or expedient'. This provision implies that the Industrial Court may award both the pecuniary and the non-pecuniary losses. Be that as it may, in practice, as discussed in this paper, in the vast majority of its awards, the Industrial Court tend to adhere strictly to assessment of monetary award as contained in the practice directive of 1987 without including compensation for non-pecuniary losses.

\section{ACKNOWLEDGMENT}

This research was financially supported by the Research Management Centre, International Islamic University Malaysia (Grant No. EDW B14-163-1048)

\section{REFERENCE LIST}

Ashgar Ali, Ali Mohamed. (2014). Dismissal from Employment and the Remedies, ( $2^{\text {nd }}$ edn).

Ashgar Ali, Ali Mohamed. (2005). The Remedy of Monetary Compensation in Dismissal Without Just Cause or Excuse: An Analysis. Malayan Law Journal, xxi.

Ashgar Ali Ali Mohamed. (2002). The Harsh Manner of Dismissal: A Worker's Remedy at Common Law and Statute in Selected Countries. The Journal of the Malaysian Bar Vol. XXXI (No 2) 3.

Ashgar Ali Ali Mohamed. (2015). Sexual Harassment: Liability of Sexual Harasser and Employer in Tort.

Pertanika J. Soc. Sci. \& Hum. 23 (S), 179 - 190.

Carrie R Leana and Daniel C Feldman. (1992). Coping with Job Loss. 11. 